\title{
CHAPTER THIRTEEN
}

\section{ROTTERDAM, MARITIEM MUSEUM \\ (MARITIME MUSEUM)}

\section{Address: Leuvehaven 1}

The museum had its origin in the collection of the Royal Dutch Yachting Club (Koninklijke Nederlandsche Yachtclub) in Rotterdam, to which was added a substantial private collection of objects related to navigation and shipping gathered by Prince Hendrik, son of King Willem II of the Netherlands and in function as navy officer in various ranks (1820-1879). In $185^{2}$ this collection, mostly consisting of ships' models and housed in the models room at the Willemskade in Rotterdam, was displayed in exhibition for members of the club. The collection, continually expanded since, became fully public in 1874 . It moved to a separate building, which it heretofore had shared with the Ethnographic Museum (see the introduction to the next chapter), in 1948. The Maritime Museum is the oldest of its kind in the Netherlands. Its collection includes a few documents and manuscripts connected to travel and navigation in the Ottoman Empire.

Literature: Schatkamer der scheepvaart. Honderd jaar Maritiem Museum 'Prins Hendrik' Rotterdam 15/2-10/6 1974 (Rotterdam 1974), pp. 7-64; Joh. Diepraam \& Onno Meeter, De bel luidt over 't water. Het Nationaal Scheepvaartmuseum in Antwerpen en het Maritiem Museum 'Prins Hendrik' te Rotterdam (Amsterdam 1988), pp. 51-61; Leo M. Akveld, Magnifiek Maritiem. Voorwerpen uit het Maritiem Museum 'Prins Hendrik' vertellen hun verhaal (Amsterdam 1992), pp. 8-12.

\section{H336(3)}

A passport

The passport consists of a sheet of white paper, $430 \times 270 \mathrm{~mm}$, with printed text in French on one side, to which data are added in handwriting. The document, on which a large Dutch coat of arms figures prominently, was issued to the navy officer Jean Anne Vening (1843-1893, cf. NNBWV, col. 998) at Leeuwarden on 23 May 1870 for a journey to the Ottoman Empire, Greece, Italy, the Papal States, Austria and elsewhere. To the pass are 


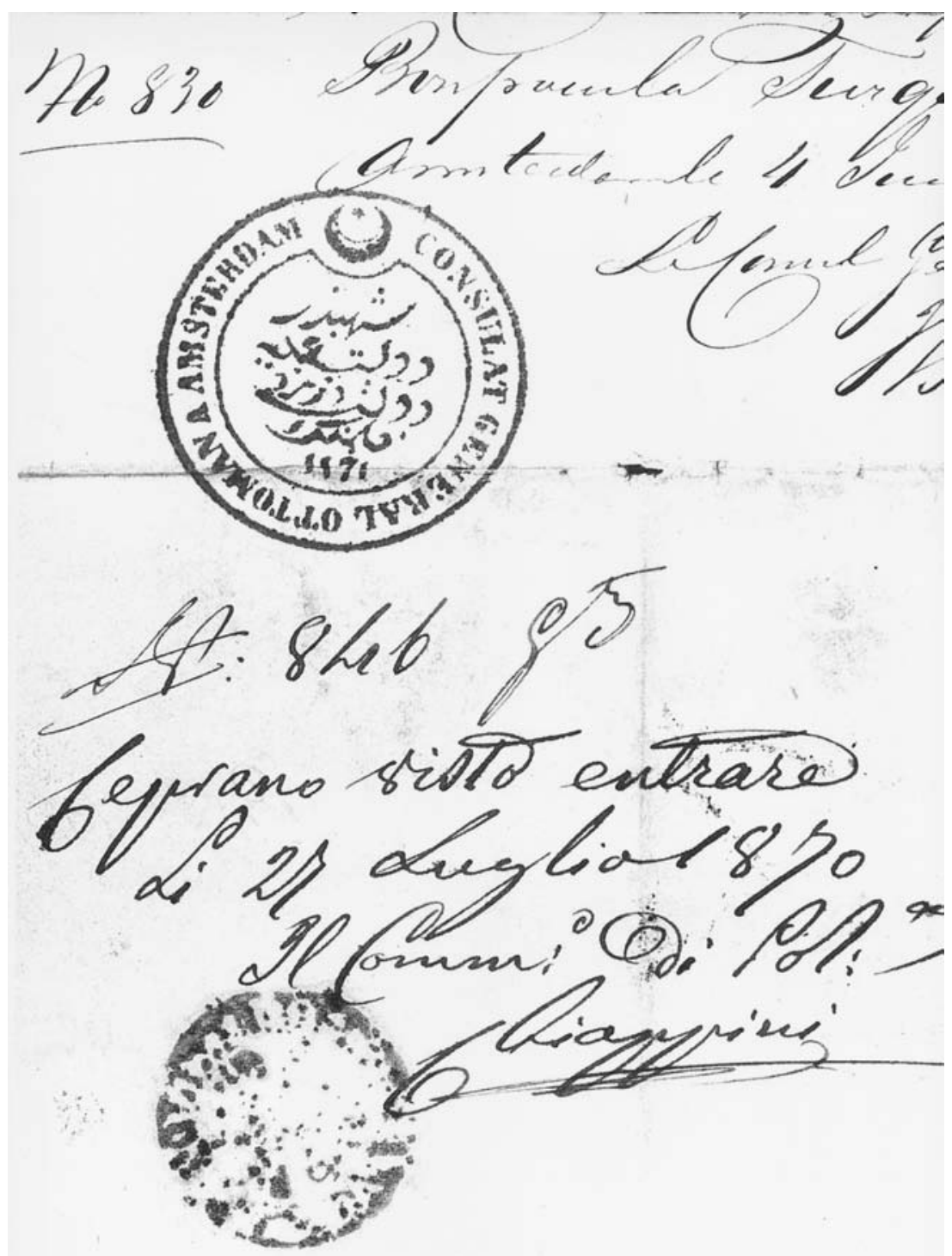

Figure 42. Rotterdam, Maritiem Museum H336(3). A visa with a stamp of the Ottoman Consulate in Amsterdam on a passport issued to a Dutch Navy officer, dated 4 June 1870 . 
added nine visas, handwritten in French and Italian, and furnished with stamps, granted in Amsterdam, Istanbul, Rome, Naples and Geneva. On the back, top right, is a visa issued by W. Pomo, Ottoman consul-general at Amsterdam, dated 4June 1870. A stamp with the Turkish text şehbender-i devlet-i 'aliye nezd-i devlet-i Felemenk and the year 1261 [1845] is added.

The passport is part of a small collection of private papers, eleven items dated 1869-1890, donated by Mrs. Kraaiveld, The Hague.

\section{H639}

\section{An Ottoman signal book}

The early 19th-century manual for signals used in the Ottoman Navy, designed and filled in by one scribe. It consists of four main parts: (1) a table with coloured pictures of flags with corresponding numbers (p. 11) and the year 1246 (1830-1831); (2) a list of ships, with indications of type and names, numbered 10 to 45 (pp. 12-13); (3) a survey (pp. 16-260) of the meaning of number codes, from 1 to 4885 , divided into sections according to subject as indicated both in Turkish, and, often, in French, beginning with the geographic directions (cihān erba'a rüzgārları gelmek gelinmek yol verüb ejglendirmek hușūṣı / vents principaux du partir et venir ainsi que de rester)-begins: 1. gel, 2. gelsün-and signals related to lying idle (kıyām hușūṣı / affaires de rester, de station — the first entry reads: 101. ḳalkmaġa

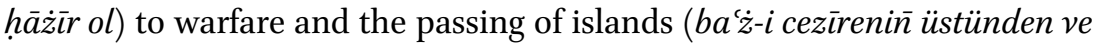
altından yolverilmesi husūṣsı), followed by a table of the letters of the alphabet, numbered 1-20 (p. 26o); (4) a survey of the number codes of signals given by lighthouses, divided into chapters ( $b \bar{a} b)$; it begins: [fenār 'alāmet] 1. [fenūr işāret] 1/1. rūzgār üstünde olan gemi yāhud gemilerile kendünizi bildirin zī rātop atacaġım çabuk olun (pp. 338-369). The section ends with a survey of the signals particular for the subsequent ships, ending (p. 369) with 2/1 1/1 fırkateyn Şāğır Tunisī. Many pages have remained blank. An owner's inscription of Brusavizāde Hüseyn Hōoca is found on f. 1a. Annotations in Russian are found on p. 1. A few financial notes, one with the place-name of İskenderun, occur on the inner front-board and p. 1. A pencil note (Signal Book in Arabic) is found on p. 8.

Bound in boards, with red leather back; white glazed paper; 378 pages; $265 \times 192 \mathrm{~mm}$ and $223 \times 140 \mathrm{~mm}$; 20 lines; $r k^{\prime} a$; multiple black borders and lines; (Turkish) headings and numbers mostly in red; see also above. Origin unknown. 


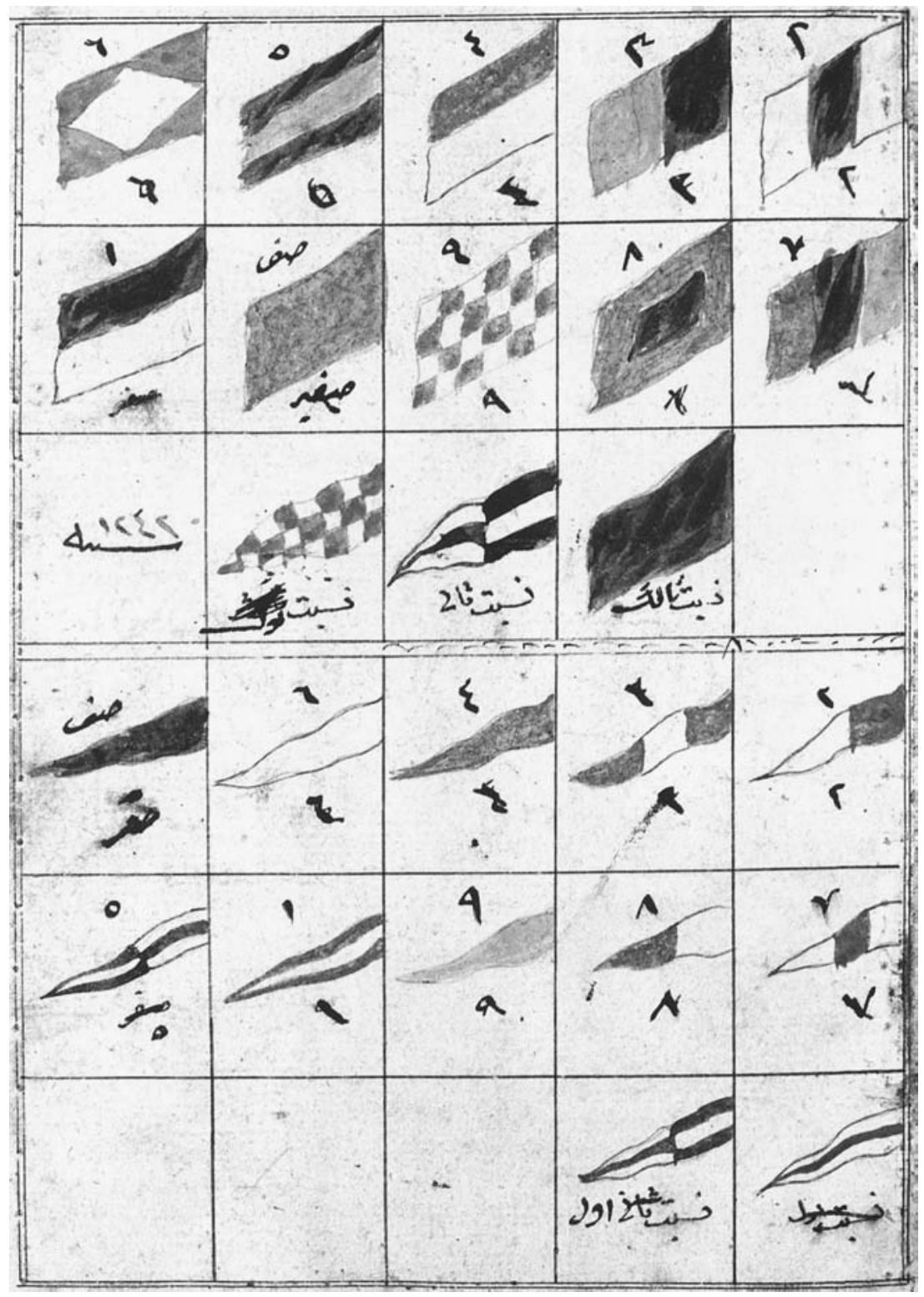

Figure 43. Rotterdam, Maritiem Museum H639, p. 11. Flags depicted in an Ottoman signal book, early 19th-century. 
262

CHAPTER THIRTEEN

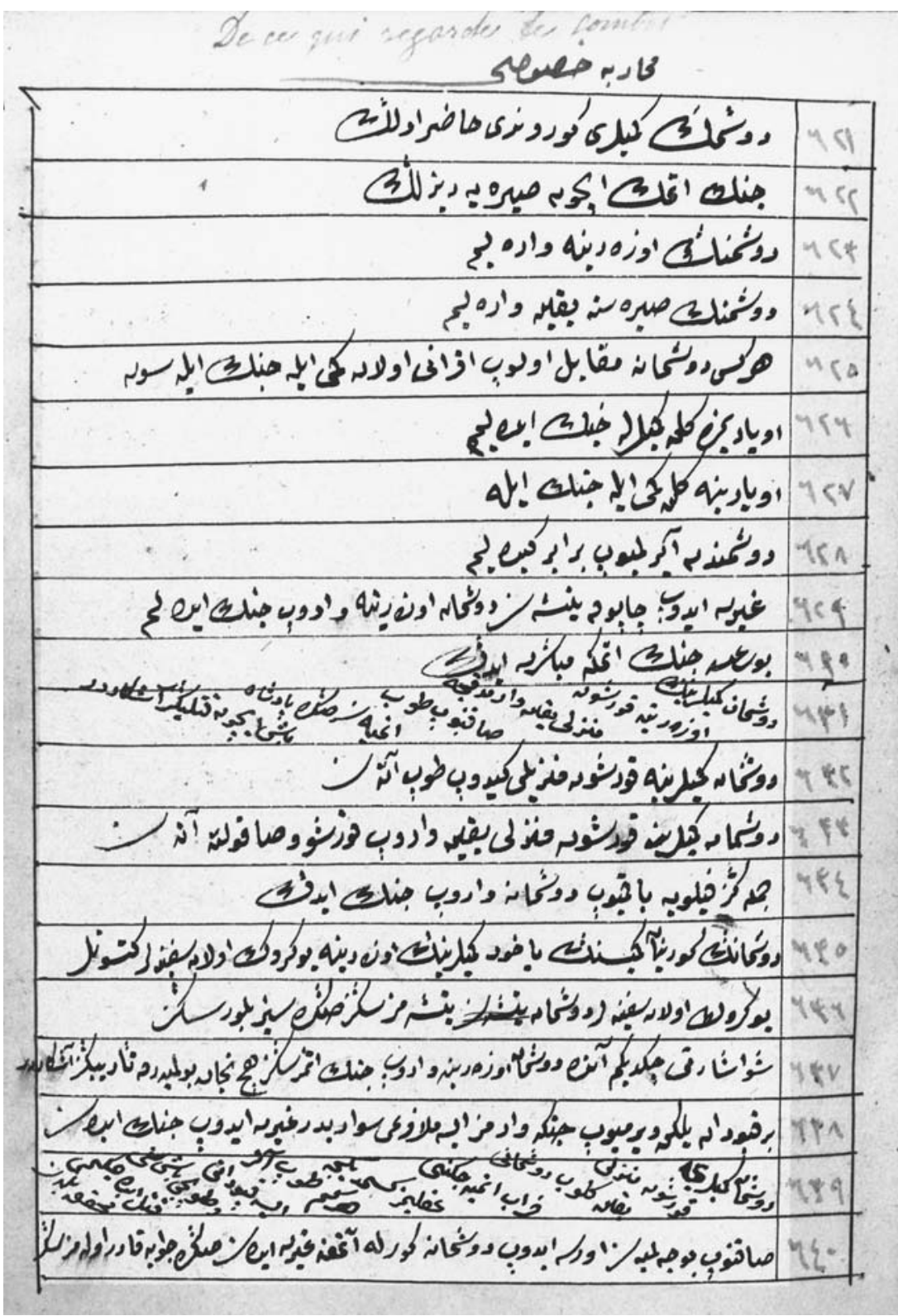

Figure 44. Rotterdam, Maritiem Museum H639, p. 47. A page of an Ottoman signal book with explanations of number codes, early 19 th-century.

Jan Schmidt - 9789004221918

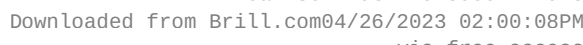

via free access 


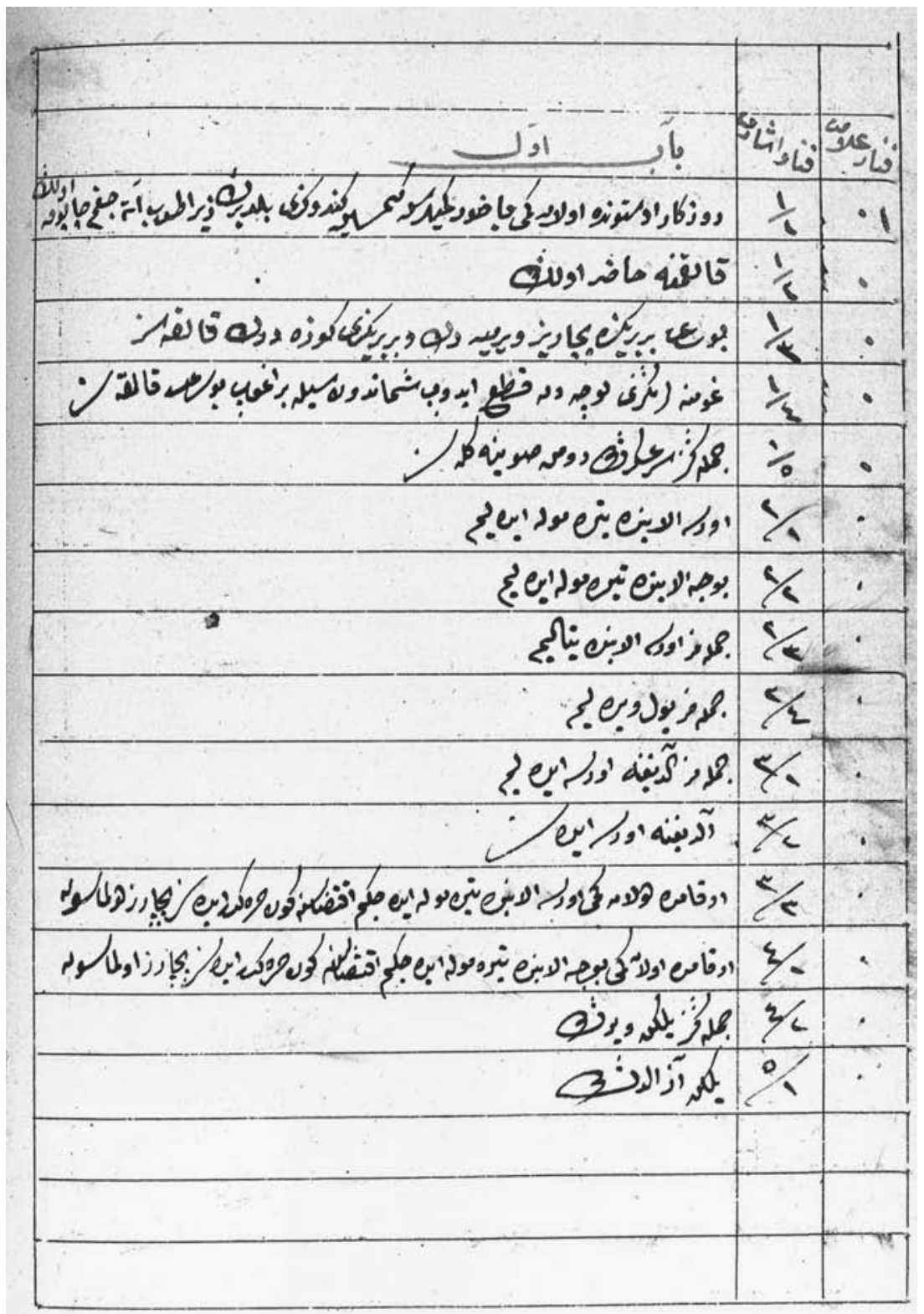

Figure 45. Rotterdam, Maritiem Museum H639, p. 338. Lighthouse codes with explanations found in an Ottoman signal book, early 19th-century. 


\section{P2316}

A passport

An original copy of a hükm-i şerīf (fermān), accompanied by a Dutch translation. The document was a letter of safe-conduct issued to Captain Metz, commander of the merchant steamer (tüccār vapur sefinesi), Fop Smit (see for a picture, Stoomvaart Maatschappij Rotterdamsche Lloyd 15 Juni 18831908, Rotterdam 1908), on request of the Dutch envoy to the Porte for a journey from Istanbul to the Black Sea; the captain was to pay a selamet resmi of 300 akçe on entering the Black Sea. It is dated 4 Rebïü l-ähir 1289 (11 June 1872). The text is headed by a tugra of Sultan 'Abdul'azìz (cf. Umur, pp. 302-305). Signatures are found below the text and on the back.

Worn cream paper which has undergone conservation treatment; $600 \times$ 480 mm; 3 lines; bold dìvānì. The Dutch translation: cream paper; $195^{\times}$ $135 \mathrm{~mm} ; 14$ lines.

Donated by H.H. Theunissen in 1926. 